\title{
Seismic microzonation based on microseismic data and damage distribution of 2006 Yogyakarta Earthquake
}

\author{
Radhitya Perdhana ${ }^{1, *}$ and Budi Eka Nurcahya $^{1}$ \\ ${ }^{1}$ Department of Physics, Universitas Gadjah Mada, Yogyakarta, 55281, Indonesia
}

\begin{abstract}
The 2006 Yogyakarta earthquake caused an extensive damage to various areas of Yogyakarta regions. The damage distribution indicates the role of local site effects during the earthquake as the damage extended from Bantul Regency in Yogyakarta Province to Klaten Regency in Central Java. Microzonation based on the damage distribution is then carried out using Horizontal-to-Vertical Spectral Ratio (HVSR) technique. From this technique, amplification factor and predominant frequency can be obtained and then spatially mapped. Inversion can also be conducted to the HVSR curves to infer the geological condition of the study area.
\end{abstract}

\section{Introduction}

The 2006 Yogyakarta earthquake caused an extensive damage in some areas of Yogyakarta region. The most affected areas were Bantul Regency in Yogyakarta Province and Klaten Regency in Central Java Province. In Bantul area the building collapse ratio reached as high as $62 \%$ as found in Pundong, Jetis, and Pleret subdistrict. In Klaten area, the collapse ratio ranges from $34-62 \%$ in the subdistricts of Prambanan, Gantiwarno, and Wedi [1].

It has been stated that the damage caused by earthquake is related to the condition of local geology in that area [2]. From the damage distribution of the 2006 Yogyakarta earthquake, it can be indicated that local site effects played a role. A study about the role of local geology in the damage distribution is then needed to mitigate future disaster potential. The study result can then be used as a guide for infrastructure building plan.

The HVSR (Horizontal-to-Vertical Spectral Ratio) had been proved to be an effective and practical tool for assessing local site effects. By analyzing the HVSR curve, the predominant frequency and amplification factor in a site can be extracted. These two parameters are related to subsurface characteristic. Predominant frequency from HVSR can be used to determine the bedrock depth, whereas amplification factor is related to the amplification of seismic waves on the ground surface because of an earthquake [2]. The HVSR curve can also be inverted to find the subsurface model in that site.

\section{Data and methods}

This study used microtremor recording from several sites in Yogyakarta Region as primary data. As secondary data to support the analysis, other data such as digital elevation model (DEM), land use map, geological map, and borehole data were also collected from other researches and public databases. Figure 1 shows the distribution of 232 measurement sites that located in Yogyakarta and Klaten region.

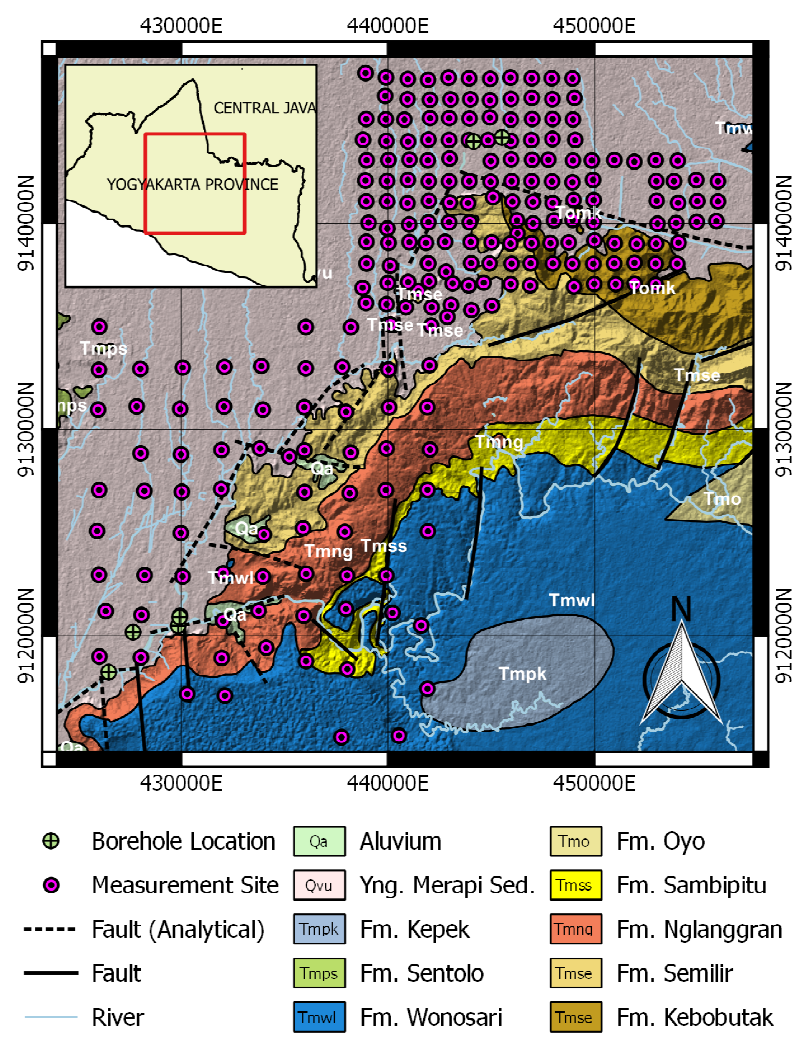

Fig. 1. Map of study area overlaid on geological map.

The research procedure is shown on Figure 2. The research began with literature study on previous researches. From this literature study, information such as regional geology of the study area and damage distribution of 2006 Yogyakarta earthquake were obtained. The next step was data acquisition to obtain microtremor recording from 233 measurement sites.

\footnotetext{
* Corresponding author: radhitya.perdhana@mail.ugm.ac.id
} 
HVSR processing method is then applied to the microtremor data to produce the HVSR curves. Picking is then done to these curves to extract the amplification factors $\left(A_{0}\right)$ and predominant frequencies $\left(F_{0}\right)$. The values of these parameters were then mapped to show their spatial distribution. Inversion is also carried out to these curves to obtain the subsurface ground model.

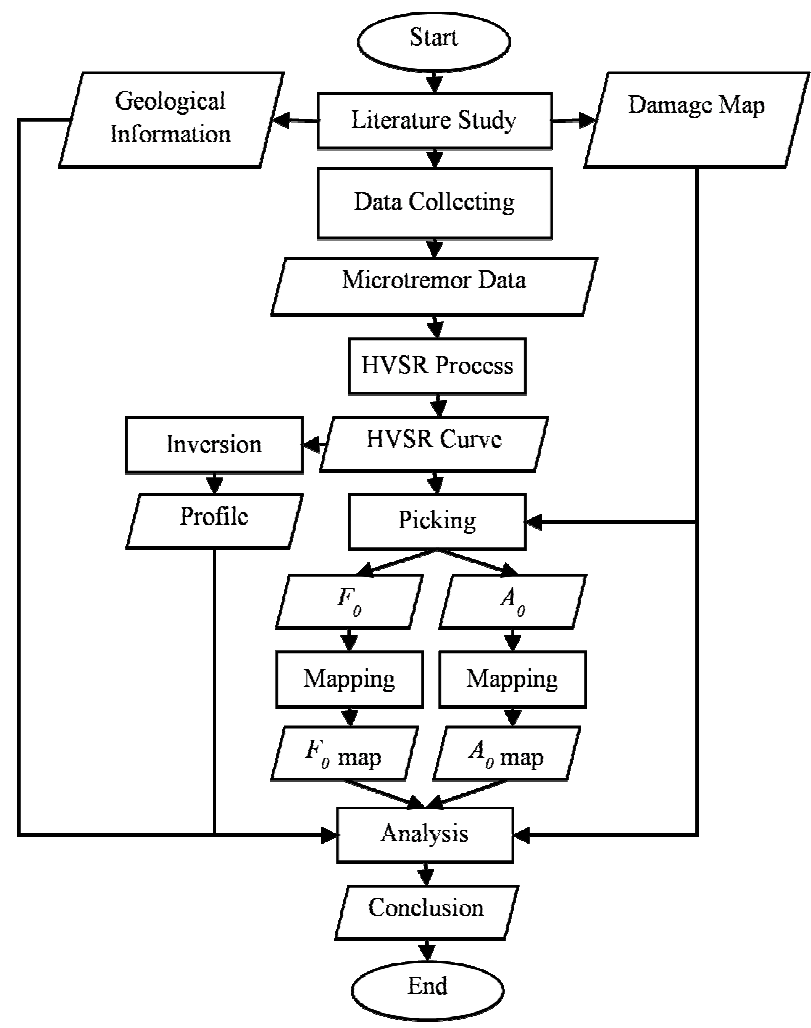

Fig. 2. Flowchart of this research.

The picking procedure to obtain the amplification factor from the HVSR curves was carried out by comparing the curves obtained from measurement sites to a curve from some reference sites. A number of reference sites were selected for these comparisons. These reference points were selected based on the damage level caused by the 2006 earthquake. From this comparison, the peak of HVSR curves which represent the amplification were identified and extracted. An example of this comparison is shown on Figure 3. In that figure, the comparison is carried out for measurements points in Prambanan region. The area on the southern part of Prambanan was heavily damaged during the 2006 earthquake. From the comparison, it is found that the peaks of HVSR curve in the $0.3 \mathrm{~Hz}$ to $3 \mathrm{~Hz}$ show a good correlation to the damage level.

The inversion procedure was carried out using Dinver software which is a part of Geopsy software package released by SESAME research program. The algorithm for inversion process in the software is the neighborhood algorithm which was built and modified by Wathelet et al. [3,4]. The assumption for this inversion procedure is that microtremor primarily consists of Rayleigh wave and that the HVSR is related to the ellipticity of Rayleigh wave. In this research, the inversion is implemented to HVSR curves from several measurement lines shown on Figure 4.

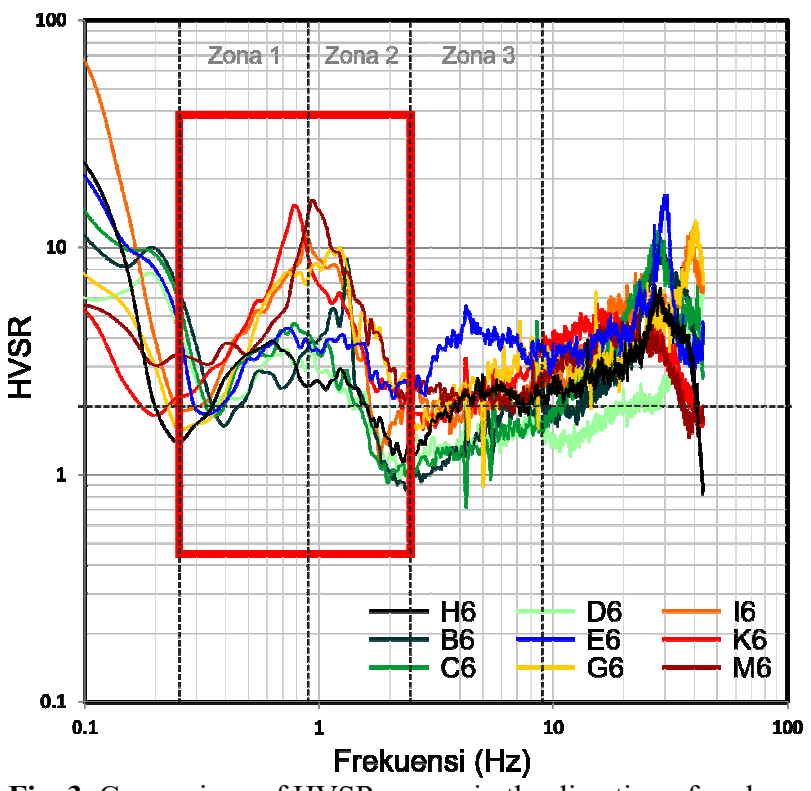

Fig. 3. Comparison of HVSR curves in the direction of norhern to southern Prambanan. The damage areas are located in the northern part of Prambanan which correspond to the peaks of HVSR curve in the frequency range of $0.3 \mathrm{~Hz}$ to $3 \mathrm{~Hz}$ (red square).

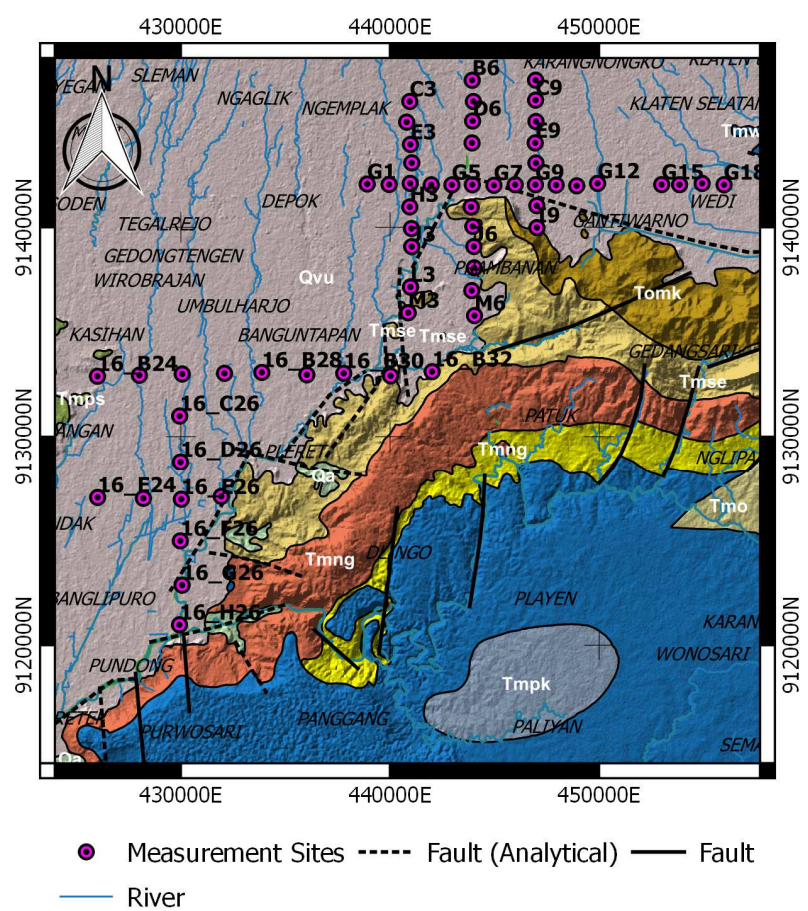

Fig. 4. Lines of measurement sites used in inversion procedure.

The reference model for inversion process in this research was based on previous researches such as [5], [6], [7], [8] and [9]. In those researches, some of the lithology and physical properties of rocks in the study area had been presented. Calibration was then carried out to correlate the HVSR curve with subsurface features. The calibration was carried out by comparing the inversion results with borehole data from previous researches. 


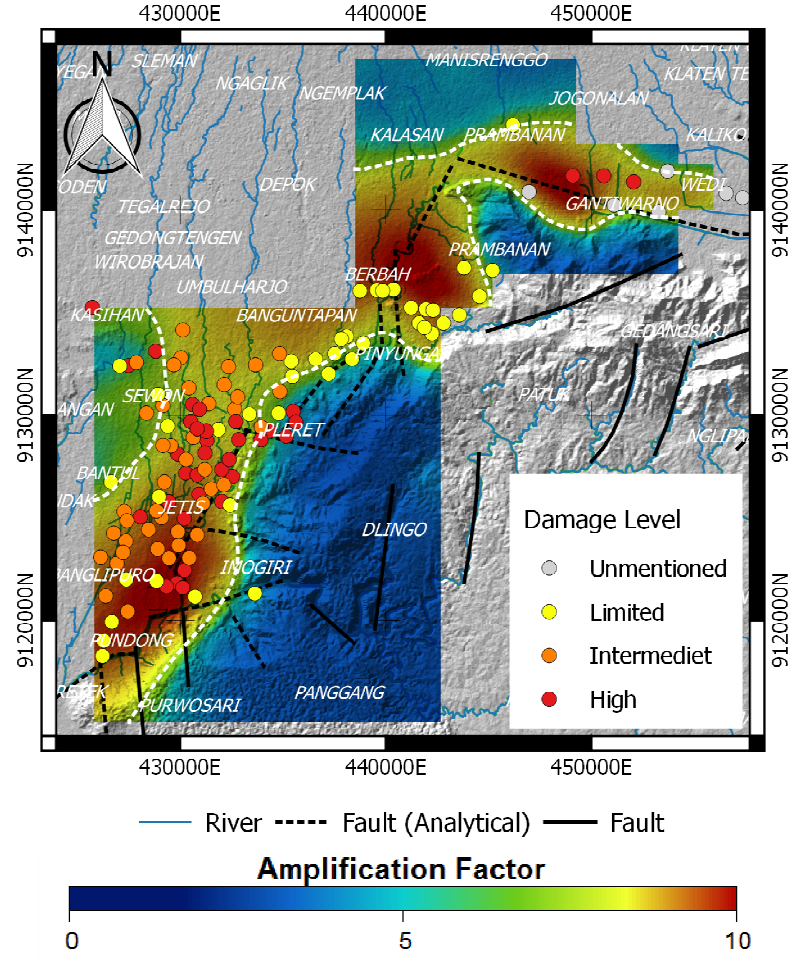

Fig. 5. Amplification factor map in the study area with circles indicate the damage distribution of 2006 Yogyakarta earthquake. White dashed line show the isolines of amplification factor corresponds with the boundary of damage area.

\section{Results and discussions}

The map of amplification factor extracted from HVSR curves is shown in Figure 5. In that figure, damage distribution from the 2006 Yogyakarta earthquake is also plotted. The damage distribution was collected from [10], [11], and [12]. The level given in this map is based on the number of collapsed building per residential area. The damage distribution is generally correlates with high value of amplification factor extracted from HVSR. The boundary of the damage area is found at the amplification factor value 6 . Zonation is then done to divide the area according to the level of amplification.

The zonation map is shown in Figure 6. The zonation map was made by dividing the interval of amplification factor from the lowest value to the highest into 3 categories. Low amplification risk is categorized by amplification factor less than 5.54, intermediate amplification is categorized by amplification factor ranging from 5.54 to 8.09 and high amplification risk is categorized as having the amplification factor higher than 8.09. From the distribution map it can be observed that the area of low amplification is found primarily on the high mountainous area such as Panggang, upper Imogiri, Dlingo and Patuk. The zone with intermediate amplification risk can be found on lower area such as northern Prambanan, Kasihan, Bantul and Pleret. The high amplification zones are located in the damage area of 2006 earthquake such as Piyungan, Pleret, Jetis, Imogiri, Berbah, Kalasan, southern Prambanan, and extends to the east as far as Gantiwarno.

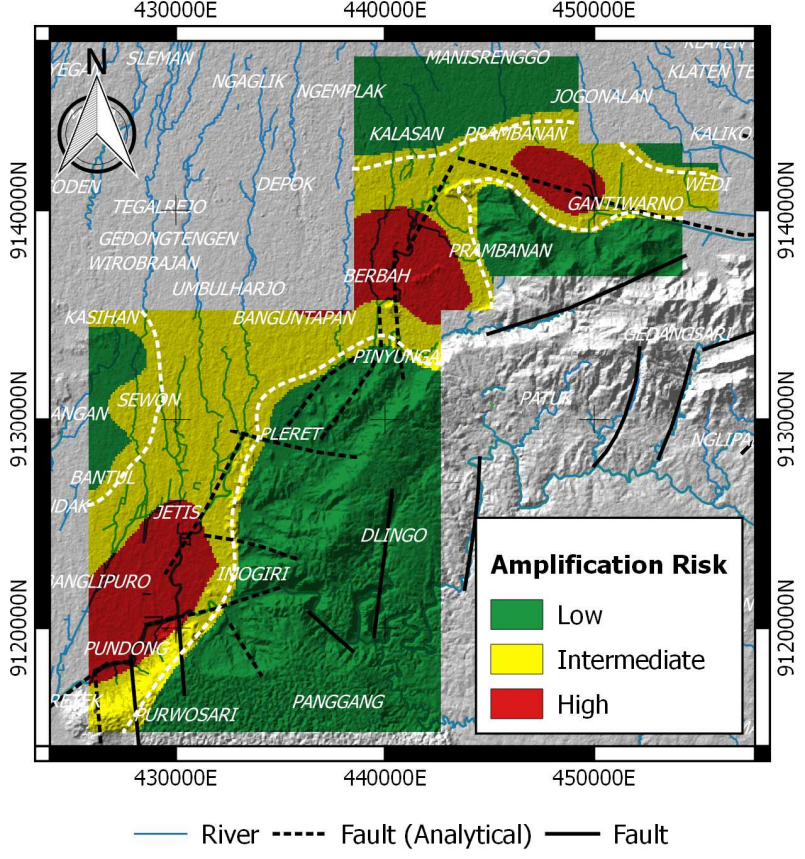

Fig. 6. Zonation map of amplification risk in the study area.

The inversion result for Prambanan area is shown in Figure 7. From that result, it is estimated that the bedrock depths in Prambanan area are around 80-100 meters. The bedrock depths are higher towards the southern area of Prambanan and reaching up to 160 meters. In the eastern part of Prambanan area around Wedi subdistrict, there found from the inversion profile a basin-like feature. This feature is interpreted to be the Wedi Basin that had been detected in the previous study [13]. On the other hand, in the western part of Prambanan area, around Kalasan, an offset to the bedrock surface from the ground profile section interpreted to be the manifestation of Opak Fault. A fault

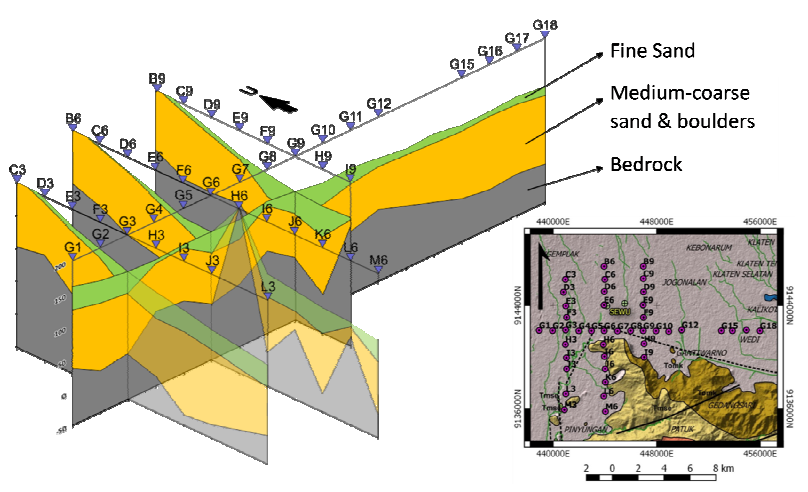

system that presumably splits the Yogyakarta Region.

Fig. 7. 3D section of ground profile model in Prambanan area from the inversion result.

The inversion result from Bantul area is shown in Figure 8. From the inversion result it is found that the bedrock depths in this area are relatively shallow compared to Prambanan area. In this area, the bedrock depths are around 40-60 meters in average. To the eastern part of this area, the bedrock depths are increasingly deeper. The maximum depths in the eastern area of Bantul are around 60-100 meters. This deep area 
is interpreted to be the manifestation of Opak Fault in

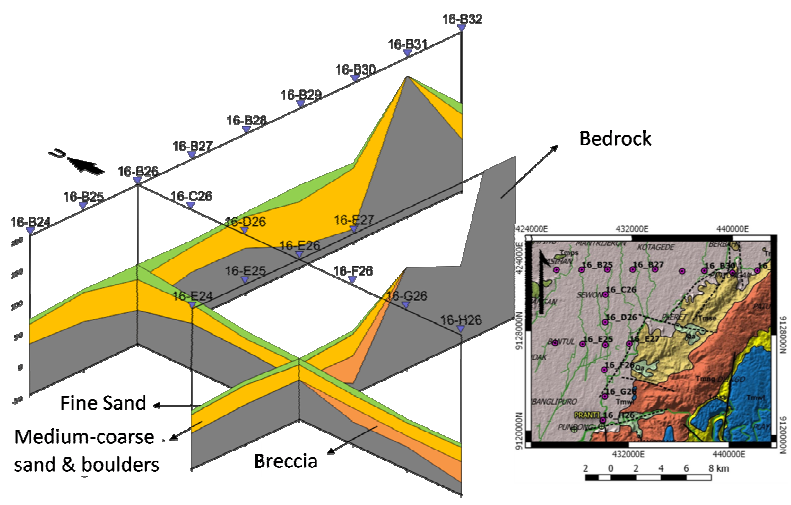

Bantul area.

Fig. 8. 3D section of ground profile model in Bantul area from the inversion resultOnline references will be linked to their original source, only if possible. To enable this linking extra care should be taken when preparing reference lists

\section{Conclusion}

Based on the analysis of HVSR and damage distribution of 2006 Yogyakarta earthquake it can be concluded that the distribution of damage area is in concord with the amplification map. From this result, the map of amplification factor can be used as guide for future development and planning. A more detail survey and analysis is recommended.

From the inversion result, the geological condition of the study area can be described. Prambanan area generally has the bedrock depths which range from about 80 to 100 meters. The sediment is mostly consists of coarse sand with andesite boulders. Southwards, the layer of fine sand at shallow depths is inferred to be thicker. In Gantiwarno area the bedrock depths are approximately around 100 to 130 meters. The content of fine-grained soft sediments in this area is presumably higher than in the northern part of Prambanan. The thickness of this layer is inferred to be around 30 to 40 meters. The area of Berbah and southern Prambanan are a deep basin area with the bedrock depths around 120 to 160 meters. The lithology of the sediment which filled the basin is assumed to be the same as in the northern Prambanan. The content of fine-grained sediments in this area is presumably higher compared to northern part of Prambanan. The bedrock depths in Bantul area are about 30-60 meter. In the eastern part the bedrock depths increase, reaching up to around 80 meters. In the area of Jetis, Imogiri and Pundong there consists a layer of breccia with thickness reaching up to 50 meters.

\section{References}

1. H. Murakami, D. Pramitasari, R Ohno, Human casualty and damage distribution in relation to seismic intensity in the 2006 central java earthquake in indonesia (14 ${ }^{\text {th }}$ World Conference on Earthquake Engineering, Beijing, 2008)
2. Y. Nakamura, Clear Identification of Fundamental Idea of Nakamura's Technique and its Applications, $\left(12^{\text {th }}\right.$ World Conference on Earthquake Engineering, Auckland, 2000)

3. M. Wathelet, D. Jogmans, M. Ohrnberger, Near Surf. Geo. 2, . 211 (2004)

4. Wathelet, M., Geoph. Res. Lett. 53, 1 ( 2008)

5. Efriansyah, Hubungan antara sifat kekompakan batuan dengan nilai amplifikasi dari pengukuran mikrotremor di daerah bantul daerah istimewa yogyakarta" (Universitas Gadjah Mada, Yogyakarta, 2007)

6. A. Murtono, Analisis mikrotremor dengan metode hvsr (nakamura) untuk mikrozonasi gempabumi daerah candi plaosan dan sekitarnya, kabupaten klaten, provinsi jawa tengah, (Universitas Gadjah Mada, Yogyakarta, 2013)

7. R. C. Putra, Analisis frekuensi dan amplifikasi mikrotremor dalam menentukan tingkat kerentanan gempabumi di daerah candi prambanan dan sekitarnya kabupaten klaten propinsi jawa tengah (Universitas Gadjah Mada, Yogyakarta, 2013)

8. S. Winardi, B. Toha, M. Imron, D. H. Amijaya, IJOG 8, 13 (2013)

9. Hesti, Identifikasi Karakteristik Dinamika Sedimen Berdasarkan Analisis Mikrotremor di Daerah Prambanan Kabupaten Sleman Propinsi DIY dan Kabupaten Klaten Propinsi Jawa Tengah (Universitas Gadjah Mada, Yogyakarta, 2017)

10. Anonym, Preliminary Damage Assessment: Java Earthquake, 2006 (UNOSAT, 2006)

11. Sutikno, Forum Geografi, 21, 1 (2007)

12. J. Koseki, M. Yoshimine, T. Hara, T. Kiyota, R. Ireno, S. Goto, Y. Agustian, Soils and Foundation 47, 937 (2007)

13. Marjiyono, Ratdomopurbo, Suharna, M. H. H. Zajuli, R. Setianegara, J.G.S.M. 15, 3 (2014) 